\title{
Managerial and Disciplinary Responses to Abandoned Acquisitions in Bidding Firms: A New Perspective
}

\section{Michael McCann* and Robert Ackrill}

\begin{abstract}
Manuscript Type: Empirical

Research Question/Issue: Existing research suggests that internal and external corporate governance mechanisms substitute for one another to mitigate agency problems in bidding firms. This paper tests whether the interaction between these mechanisms is more complementary.

Research Findings/Insights: While there is evidence for disciplinary responses to bids for unrelated targets involving strategic retrenchment and significant asset divestment, the influence of the information conveyed by this characteristic on the likelihood of post-abandonment discipline is not amplified when boards are less independent.

Theoretical/Academic Implications: The results suggest that certain characteristics are used to distinguish between abandoned bidders which require discipline and those that do not. However, our findings do not suggest that interaction between internal and external governance mechanisms is contingent on board independence. Instead, these interactions between shareholders and boards seem to be contingent on a range of company, industry, and situation-specific factors.

Practitioner/Policy Implications: While policy in the UK has focused on board independence as a means of effective corporate governance, our results suggest that this is not a panacea. Effective governance involves active owners, communicating their interests to boards, and boards responding accordingly. Further encouragement of such communication before, during, and after acquisitions will improve signals to managers that shareholders can target the necessary discipline of those whom they perceive to need it most.
\end{abstract}

Keywords: Corporate Governance, Agency Theory, Mergers and Acquisitions, Anglo-American Environments

\section{INTRODUCTION}

$\mathbf{M}$ erger and acquisition activity represents an important means of industrial reorganization, ideally delivering enhanced revenues and/or reduced costs for the firms involved. However, acquisition decisions can be a manifestation of agency problems that arise out of the separation of ownership and control (Berle \& Means, 1932; Jensen \& Meckling, 1976; Ross, 1973). Acquisitions are one way through which entrenched managers pursue their own preferences at the expense of shareholders, destroying value in the process. Attempts to prevent such behavior lie at the heart of much governance reform in the UK and US over the last two decades.

Agency theory predicts that dispersed ownership (Chen, Harford, \& Li, 2007; Gaspar, Massa, \& Matos, 2005), weak board monitoring (Bhagat \& Black, 2002; Tian \& Twite, 2011),

*Address for correspondence: Michael McCann, Nottingham Business School, Nottingham, Trent University, Nottingham NG1 4BU, UK. Tel: +44(0)115 8482451;

E-mail: michael.mccann@ntu.ac.uk and poor incentives (Cornett, Hovekimian, Paulia, \& Tehranian, 2003; Goranova, Alessandri, Brandes, \& Dharwadkar, 2007) provide a governance environment enabling value-destroying bids. However, even when corporate governance mechanisms are well-designed, value-destroying bids can still be proposed (O'Sullivan \& Wong, 2005). In such circumstances, the literature suggests that the bidding process can substitute effective external governance mechanisms for weak internal ones, preventing proposed "value-reducing" bids by powerful, entrenched managers pursuing their own agenda, from progressing (Lehn \& Zhao, 2006; Paul, 2007). Indeed, according to data from the Takeover Panel, the organization which regulates acquisitions in the UK, between 2000 and 2010, on average 10 percent of bids were abandoned annually at an advanced stage.

Paul (2007: 774) argues that abandonment itself is the finale of the disciplinary process, stating that "corrective responses are unnecessary for terminated bids." However, is abandonment the disciplinary finale? Several studies find ambiguous evidence surrounding discipline in bidders after abandoned bids (see Holl \& Pickering, 1988 and Taffler \& Holl, 1991). However, this work is dated and focuses on narrow financial measures of performance after abandonment. The present 
paper is motivated by the need to update analysis of governance mechanisms involving abandoned acquisitions in the light of conceptual and regulatory developments over the last 20 years. For instance, Hirshleifer and Thakor (1994) develop a model whereby internal and external governance mechanisms interact, not as substitutes, but as complements. Boards of directors of firms which are targets of acquisitions use market signals to improve their knowledge of the performance of senior managers. Despite abandonment, such boards discipline the senior managers. Evidence of such discipline in targets after abandoned acquisitions has been found by Denis and Serrano (1996) and Limmack (1994).

More recently, corporate governance reform has emphasized the role of "independent" directors in monitoring and disciplining the actions of senior managers, including CEOs. Several papers have modeled interactions between executive and independent directors in the context of asymmetric information (for a survey, see Adams, Hermalin, \& Weisbach, 2010). Of particular relevance for the analysis of corporate acquisitions is the model of Adams and Ferrera (2007). Their framework provides an explanation for monitoring and discipline by boards of directors when information is revealed about the viability of investment decisions.

In this paper, we provide an empirical analysis of the interactions of internal and external governance mechanisms surrounding abandoned acquisitions and their aftermath. Unlike most agency models which look at a limited subset of relationships, our framework blends existing agency theory conceptions of internal governance mechanisms surrounding board monitoring, with ideas about information revelation through the market for corporate control and managerial and disciplinary responses to abandonment.

We extend previous work to hypothesize that, in certain circumstances, internal mechanisms (boards) and external governance mechanisms (bidding process) interact in a complementary way to discipline senior managers of bidders in abandoned acquisitions. So, even though managers abandon a bid driven by their own self-interest, there may still be further disciplinary reactions by boards of directors to information revealed during the bidding process.

The analysis advances existing research into corporate governance, by incorporating more direct managerial and disciplinary responses to corporate decisions. Such responses include organizational restructuring (Haynes, Thompson, \& Wright, 2000; Perry \& Shivdasani, 2005), management turnover (Huson, Parrino, \& Starks, 2001; Kennedy \& Limmack, 1996) and financial restructuring (Barclay \& Smith, 1995), as well as whether such bidders become the target of disciplinary acquisitions themselves (Mitchell \& Lehn, 1990). However, there has been no previous attempt to analyze such responses to acquisitions and abandonment decisions. Further, this characterization of managerial and disciplinary responses enables the research to produce novel perspectives by tracing causal links between them - for instance, CEO replacement can lead to organizational restructuring involving the unwinding of their past expansionary investment program.

Our framework incorporates much broader conceptions of information revelation than previous work, which concentrates on narrow interpretations of share price reactions to bid announcements. Much existing research focuses on the contribution of factors like financing, target relatedness, target management resistance, and the presence of rival bidders to the likelihood of abandonment itself (see Muehlfeld, Sahib, \& Van Witteloostuijn, 2007). In contrast, we focus on their informational content, notably the information they may convey regarding the motives of managers in proposing an acquisition.

We test the predictions of our hypotheses using a sample of bidders constructed from abandoned bids in the UK between 1998 and 2008. While many different types of company abandoned bids during this period, we adopt theoretical sampling to identify 53 public limited companies (Plcs). These are joint stock companies, more likely to suffer from the agency problems that enable self-serving bids by managers (Jensen \& Meckling, 1976).

Our findings suggest that bids for unrelated targets increase the likelihood of significant asset divestment and the refocusing of activities after abandonment. This supports the proposition that the abandoned bids were motivated by excessive diversification by managers. However, less independent boards do not accentuate the impact of this characteristic on the likelihood of strategic changes and significant asset divestments. Consequently, while our results imply some sort of governance mechanism at work, they do not suggest that board independence is an important factor determining the extent of discipline. Instead, internal and external governance mechanisms seem to interact in a more complex manner.

The paper is structured as follows. The next section reviews the literature on disciplinary processes in acquisitions and develops a framework explaining the interaction of board composition and bid characteristics in producing post-abandonment discipline. We use the framework to propose hypotheses about the anticipated impact on post-abandonment discipline. The following section explains the data and research design. Then, the results are presented and discussed. The final section is the conclusion, including limitations of the current research, recommendations for further work and implications of the study.

\section{LITERATURE REVIEW AND HYPOTHESIS DEVELOPMENT}

Agency theory predicts that acquisitions can be a manifestation of the principal-agent problems proposed by Jensen and Meckling (1976). In circumstances where there are poorly functioning internal governance mechanisms, entrenched managers may use acquisitions to empire-build (Jensen, 1986) or diversify their firm-specific risk (Amihud \& Lev, 1981). This produces bids which destroy shareholder value. The market for corporate control is viewed as an external corporate governance mechanism which substitutes for weak internal governance, to discipline senior managers for proposing such bids (Manne, 1965). There is an extensive literature analyzing the governance role of the acquisition process in alleviating principal-agent problems (for a review of the literature, see O'Sullivan \& Wong, 2005). It has been proposed that information revealed, primarily through share price reactions to bid announcements, enables the market for corporate control to distinguish value-enhancing bids in shareholders' interests from value-destroying bids in managers' interests. This suggests some sort of governance mechanism at work. However, 
despite suggestions by literature surveys (cf. Wong \& O'Sullivan, 2001), research has not fully analyzed the governance mechanisms surrounding abandoned acquisitions, particularly the nature of the interaction between internal and external governance mechanisms that may produce abandonment.

Further, existing research concludes that abandonment is the disciplinary finale (Paul, 2007). Consequently, there has been partial analysis of discipline beyond the point of abandonment, although some dated work does provide some limited evidence for managerial and disciplinary responses to abandonment in bidding firms. Pickering (1983), for example, found mixed consequences for bidding firms. While the owners of some bidding firms took no action against managers in response to abandonment, others responded with a range of internal actions, such as changing management, methods of production, or undertaking reviews of products and markets. In some cases, he observed substantial organizational restructuring. Subsequent work which focused on financial performance in bidders after abandonment found conflicting evidence regarding discipline (Holl \& Pickering, 1988; Taffler \& Holl, 1991). Beyond these narrow measures of financial performance, there has been little systematic attempt to analyze the nature and extent of discipline after abandoned acquisitions or explain why they occur. An analysis is thus timely given the conceptual and empirical developments in corporate governance since that research was conducted.

This section will review the literature and construct a novel framework which blends existing agency theory conceptions of internal governance mechanisms relating to board monitoring, with ideas about information revelation in the bidding process, to derive testable hypotheses regarding the relationship between the effectiveness of board monitoring, information revealed through transaction characteristics, and the likelihood of post-abandonment discipline. This will extend knowledge about the nature and effectiveness of interactions between internal and external governance mechanisms in preventing acquisitions which destroy shareholder value.

Agency problems tend to arise as a result of the separation of ownership and control. Where dispersed ownership is likely to create agency problems, boards of directors are viewed as an internal governance mechanism to oversee, monitor, and discipline top management, including the CEO (Demb \& Neubauer, 1992). In relation to investment decisions, such as acquisitions, this means that boards should have a role in ensuring that top management choose value-enhancing acquisitions. Corporate governance reform has emphasized the extent to which boards are "independent" of managers. For example, the most recent revision of the UK Corporate Governance Code (Financial Reporting Council, 2012: 11) states, "the board should determine whether the director is independent in character and judgement and whether there are relationships or circumstances which are likely to affect, or could appear to affect, the director's judgement."

The evidence surrounding the effectiveness of board independence on firm performance is mixed. A number of studies show conflicting results (cf. meta-analyses by Bhagat \& Black, 2002; Dalton, Daily, Ellstrand, \& Johnson, 1998; Gillette, Noe, \& Starks, 2008 and Tian \& Twite, 2011). Indeed, in their model, Kumar and Sivaramakrishnan (2008) suggest an ambiguous relationship between board independence and their monitoring of a CEO. They accept that, while independent directors are more inclined to monitor and discipline senior managers, even less independent directors may enhance their monitoring of CEOs in circumstances where their equity-based compensation is dependent on management performance.

Research suggests that the key aspect regarding the effectiveness of boards involves information asymmetry, where independent directors have less information than executive directors and the CEO (Holmstrom, 2005). Certain empirical findings provide evidence for this asymmetry. Ravina and Sapienza (2010) analyze the relative profitability of trades in firms' shares by inside/ outside directors. Their findings show that insiders do better, suggesting they have better access to information. Several similar models have been developed which attempt to explain the process of information transmission within boards (e.g., Dominguez-Martinez, Swank, \& Visser, 2008; Hermalin \& Weisbach, 1998). Adams and Ferrera (2007) develop a model where CEOs can influence the decisions of boards by controlling information released to independent directors about the viability of investment decisions. Board independence is an important aspect of the model, influencing the CEO's incentive to share information about the payoffs from an investment. They demonstrate that, if boards could take control over decision making in all circumstances, it is in the CEO's interest to share the information, ensuring only value-enhancing investments are pursued. The key aspects of the model are the ability of a board to exert control and the personal cost this imposes on a CEO - they do not like losing control. Exerting control has a cost for boards, but this cost falls with greater board independence, as such boards find it easier to confront CEOs and extract the necessary information.

The implication of these models is that more independent boards should ensure, ex ante, that any takeover bids are value-enhancing. In such circumstances, abandonment should not produce disciplinary responses. However, less independent boards will find it more difficult to confront managers, exert control, and extract full information about the implications of an acquisition. Consequently, value-destroying bids following managers' objectives may be pursued. In such circumstances, we propose that it takes the additional informational signals provided through the acquisition process to encourage such boards to confront managers and exert control. We propose they force abandonment and discipline the managers subsequently. This is the process by which we argue that internal governance (board monitoring) and external governance through the acquisition process interact to discipline managers for proposing value-destroying bids. Consequently, we propose the following hypothesis:

\section{Hypothesis 1. Less independent boards increase the likelihood of post-abandonment discipline.}

The release of new information during the bidding process can have a significant impact on the risk and returns associated with a particular bid and, therefore, on the bid outcome (Hotchkiss, Qian, \& Song, 2005). Implicitly, the nature of the information revealed can also influence the response of firms to abandonment. It is proposed that negative information may be revealed about the motives of management. Interpretation of these signals can provide less independent boards 
with the justification to exert control and force abandonment. This should produce discipline of senior management subsequently.

The share price reaction to bid announcements has been identified in the literature on acquisitions as the clearest form of information revelation, signaling the market's estimation of the perceived benefits from an acquisition. Several studies report that bidders are more likely to abandon proposed corporate acquisitions when the share price reaction to announcements is negative (Chen et al., 2007; Luo, 2005; Masulis, Cong, \& Xie, 2009). This suggests that firms may "listen to the market" when deciding whether to pursue a bid. Chang and Suk (1998) distinguish between abandonments initiated by targets and those initiated by bidders. They found that when targets initiated abandonment, abnormal returns to bidders were not significantly different from zero. However, when bidders initiated abandonment, the average abnormal returns were positive, indicating that the market reacted positively to boards responding appropriately to information signals.

Further evidence for an informational role for share prices in corporate governance is found by Lehn and Zhao (2006). They found that CEOs who complete acquisitions associated with lower returns around announcement face a higher probability of being replaced, compared to CEOs who cancel acquisitions anticipated to reduce shareholder wealth. This suggests a disciplinary response to poor acquisition decisions; boards replaced CEOs who failed to respond to market signals. This tended to be followed by disciplinary restructuring involving asset divestment. This outcome is supported in a study by Paul (2007). She found that those who do respond by abandoning bids keep their jobs. However, there was no report of what happened after that.

The difficulty of interpreting the informational content of share prices is in discerning the source of the perceived value-destruction; specifically managerial self-interest arising from principal-agent conflicts. Therefore, an analysis of the relationship between the share price reaction to bid announcements and post-abandonment discipline would add evidence about whether the information signal was related to perceived agency problems in the firm, manifested in the abandoned bid, or due to other factors. Therefore, the following hypothesis is proposed:

Hypothesis 2. Greater negative share price reactions to bid announcements increase the likelihood of post-abandonment discipline.

Further, in our framework, we propose that it is the use of this information by less independent boards to exert control which leads to post-abandonment discipline. Consequently, we can propose the following hypothesis:

Hypothesis 2a. Lower board independence will increase the impact of negative share price reactions to bids on the likelihood of post-abandonment discipline.

The type of bid financing is another transaction characteristic which is used to interpret the motivation for a bid. Bidders can pay with cash, their own shares, or some combination of the two. Decisions around financing are complex and there are multiple interpretations, several of which may suggest agency problems within a firm. Jensen (1986) hypothesizes that senior managers of firms with insufficient projects with positive net present values (NPVs), may use excess cash to pursue value-destroying acquisitions, rather than distribute the free cash to shareholders. The bids are financed by cash so the senior managers can retain control over resources. Testing this, Gregory (2005) found a significant negative relationship between the performance of acquisitions and the extent of free cash held by bidders.

Another interpretation of the financing decision relates to asymmetric information through uncertainty (Myers \& Majluf, 1984): greater uncertainty about the outcome of a bid encourages the use of equity financing. Alternatively, directors may use "share power" (overvalued equity) to acquire assets at an effective discount (Shleifer \& Vishny, 2003). The latter interpretation suggests a resourceful bid to acquire a target cheaply. As a result of these different conceptualizations, definitive statements about the relationship between financing and abandonment are difficult (O'Sullivan \& Wong, 2005). In this study, we test the proposition that the use of cash signals a valuedestroying bid, which reflects directors' desire to use free cash flow to retain control over resources. Such information could be used by boards to force abandonment and instigate disciplinary responses subsequently. Conversely, equity bids signal a value-enhancing bid that is in shareholders' interests. Thus, the following hypothesis is proposed:

Hypothesis 3. Higher cash financing increases the likelihood of post-abandonment discipline.

Further, in our framework, we propose that it is the use of this information by less independent boards to exert control which leads to post-abandonment discipline. Consequently, we can propose the following additional hypothesis:

Hypothesis 3a. Lower board independence will increase the impact of cash financing on the likelihood of post-abandonment discipline.

Further information about the motives for a bid can be derived from the identity of the target. Bids for related targets are anticipated to produce clearer synergistic benefits, enhancing shareholder wealth, supporting efficiency from economies of scale and scope as important motives for such acquisitions (Peltier, 2004). Related acquisitions may also produce benefits for corporate governance, as it is easier to assess the performance of managers in more focused firms.

Meanwhile, bids for targets in unrelated sectors will not produce the same level of synergistic benefits - at best related to finance, administration, and governance. Further, diversified firms can create corporate governance problems as it is more difficult to discern managerial performance across an array of unrelated or limitedly related activities. Such bids may be a sign of excessive diversification arising out of principal-agent conflicts with managers of bidding firms who are empirebuilding or seeking to reduce their personal risk at the expense of shareholders (Amihud \& Lev, 1981; Lane, Cannella, \& Lubatkin, 1998). Hence, unrelated bids may be a sign of such managerial motives. Markets may signal this information to boards, which force abandonment to prevent detrimental consequences for shareholder wealth. This should elicit further discipline afterwards. Therefore, we propose the following hypothesis: 
Hypothesis 4. Bids for an unrelated target increase the likelihood of post-abandonment discipline.

Further, in our framework, we propose that it is the use of this information by less independent boards to exert control which leads to post-abandonment discipline. Consequently, we can propose the following additional hypothesis:

Hypothesis 4a. Lower board independence will increase the impact of bids for unrelated targets on the likelihood of postabandonment discipline.

This review indicates a gap in the literature surrounding the agency theory of corporate governance and the nature and extent of discipline, if any, imposed on managers surrounding abandoned acquisitions. In summary, we address this gap by proposing hypotheses regarding the interaction of internal governance mechanisms with information revelation in the bidding process, indicating bids driven by managerial selfinterest arising out of managerial-shareholder conflicts.

\section{METHOD}

\section{Research Design and Sample Selection}

The hypotheses are tested cross-sectionally using a sample of UK companies which have abandoned bids between 1999 and 2008. A cross-sectional design is chosen because it is the variation across bids, in terms of board monitoring and transaction characteristics, which will determine differences in the extent of post-abandonment discipline. Agency theory proposes joint stock companies are those most likely to have the principal-agent problems, which give managers the scope to make "value-reducing" bids (Jensen, 1986). Consequently, the sample of firms in the present study is drawn from UK public limited companies (Plcs). The bids are sourced from the Takeover Panel - the institution which, under the auspices of the London Stock Exchange, regulates bids for UK registered companies. Table 1 shows the chronological distribution of both the population and the sample over the period.

TABLE 1

Annual Number of Abandoned Acquisitions in the UK

\begin{tabular}{rrrr}
\hline & Total & Sample & $\%$ \\
\hline 1999 & 33 & 6 & 18.18 \\
2000 & 25 & 2 & 8.00 \\
2001 & 6 & 1 & 16.67 \\
2002 & 8 & 3 & 37.50 \\
2003 & 12 & 9 & 75.00 \\
2004 & 11 & 3 & 27.27 \\
2005 & 18 & 5 & 27.78 \\
2006 & 13 & 9 & 69.23 \\
2007 & 11 & 7 & 63.64 \\
2008 & 9 & 8 & 88.89 \\
& 146 & 53 & 36.30
\end{tabular}

Source: Panel on Takeovers and Mergers Annual Reports: 1999-2008
A total of 146 bids were abandoned, but this includes not only the UK Plcs desired for the present study, but also UK private limited companies and foreign bidders. In addition, issues of data availability and companies' involvement in multiple abandoned bids reduced the sample for analysis to 53 . Even so, this is 36.3 percent of abandoned bids in the UK over this time period and is sufficient to be deemed representative of UK public bidders and abandoned bids over the period.

\section{Data Collection and Variable Measurement}

The data for the 53 companies in the sample were collected from regulatory news statements (required statements under the listing obligations of the London Stock Exchange), company press releases, and annual reports. These were sourced from the London Stock Exchange website or individual company websites.

The dependent variable is the disciplinary response to abandonment. There are a variety of disciplinary responses identified in the recent corporate governance literature which could be consequences of interactions between internal and external corporate governance mechanisms involving bidabandonment. In this study, we use several discrete operational measures of disciplinary responses to abandonment, which suggest varying degrees of severity (see Table 2 for operational definitions of disciplinary responses). These range from changes in strategic direction and CEO replacement, to more severe responses involving changes in corporate control through disciplinary acquisitions.

Firstly, Pickering (1983) found evidence that the abandonment of a bid may lead to strategic changes within firms. We propose that such strategic changes are a disciplinary response to an abandoned bid, arising from principal-agent conflict. We identify strategic changes from appropriate statements in the sources highlighted above. For instance, one company's report stated the abandoned acquisition represented the "closing of one chapter and the opening of another," while another's annual report highlighted "strategic repositioning" within months of their abandoned bid.

Secondly, the replacement of senior management, notably CEOs, is the most common form of disciplinary response highlighted (Huson et al., 2001). CEO replacement may be a punishment for proposing acquisitions with poor prospects. Such replacement is proposed as a possible disciplinary response to information revealed by an abandoned acquisition. In identifying CEO replacement as a disciplinary response, we find evidence linking the event to abandonment. Traditionally, a time-limit of two years is adopted for such changes (Kennedy \& Limmack, 1996). Any changes after that are unlikely to be linked with the earlier abandoned bid.

Thirdly, organizational restructuring (Ahn \& Walker, 2007), and particularly asset divestment (Perry \& Shivdasani, 2005), have disciplinary interpretations if CEOs, or their successors, unwind excessive diversification previously conducted. Information about this excessive acquisitiveness is revealed during the bidding process. Abandonment is forced and disciplinary disposals occur. Firms are deemed to have made significant asset disposals if their real value of net acquisitions (disposals) is in the lowest quartile for the distribution of this variable across the cross-section of firms. In addition, a policy of asset sales is also evidenced by the analysis of statements in 
TABLE 2

Operational Measures of Post-Abandonment Events and Determinant of Significance

Dimension of discipline

Significant strategic changes

Significant management changes

Significant asset sales

Disciplinary sequence

External discipline through the market for corporate control

Operational measures

Determinant of significance

Evidence of announced changes in strategy within two years

Codes used for secondary data:

"strategic review"

"new direction,", "reorientation"

"shareholder activism"

Replacement of the chief executive within two years of abandonment

Total real value of net acquisitions (disposals) as a percentage of total assets within three years of abandonment
Binary classification

Yes - Discipline

No - No discipline

Binary classification

Yes - Discipline

No - No discipline

Binary classification

Disciplinary: Asset sales

if company is in first quartile of distribution for sample

No discipline: If company is in the second, third or fourth quartiles for distribution

Binary classification

Evidence of announced changes in strategy and/or CEO replacement followed by significant asset sales

Yes - Discipline

No - No discipline

Binary classification

Successful bid for company within 3 years of abandoned bid or bankruptcy of company within 3 years of abandoned bid
Yes - Discipline

No - No discipline company reports and regulatory news announcements. These relative determinants of significance are appropriate because the focus of the research is distinguishing the experiences of different bidding firms, not comparing the experiences of abandoned bidders with an exogenous control group. This is consistent with the approach to classification taken by Paul (2007) in her study of completed acquisitions.

In addition to analyzing these disciplinary responses discretely, we propose tracing causal links between these events after abandonment to clarify disciplinary processes. If changes in strategy and/or CEO replacements are followed by significant asset disposals, this suggests that managers are being disciplined because they pursued excessive diversification in the past. Therefore, we include a further operational measure of post-abandonment discipline where evidence of a causal link from changes in strategy and/or CEO replacement to significant asset disposals is observed.

Discipline through the market for corporate control is measured in one of two ways: either changes in control through a subsequent acquisition or through bankruptcy within three years of abandonment (Mitchell \& Lehn,
1990). A three-year time limit is adopted because any later events would be less likely to be responses to abandonment (Powell \& Stark, 2005).

The independent variables in each of the hypotheses are defined as follows. For hypothesis 1, board independence is operationalized as the proportion of non-executive directors on the board. This is included as the moderator variable to test hypotheses $2 a, 3 a$, and $4 a$. This is the standard measure adopted in many prior studies (e.g., Muth \& Donaldson, 1998). It is acknowledged that this is an imperfect measure, as being a non-executive director does not imply complete independence. However, for the sample time period it is difficult to glean ideal information from published sources.

For hypotheses 2 and 2a, the share price response to bid announcements is measured using the market model estimates of cumulative abnormal returns from days -1 to +5 . For hypotheses 3 and 3a, financing was measured by the proportion of the offer price financed using the bidder's own equity, ranging from 0 (complete cash financing) to 1 (complete equity financing). Information about bid financing was found 
in bid documents. For hypotheses 4 and $4 a$, the industrial relatedness between the bidder and the target is measured using the Standard Industrial Classification (SIC). We define a target as related if it has the same 2-digit SIC as the bidder. This is consistent with previous studies (e.g., Muehlfeld et al., 2007). This is a dummy variable which takes a value of one for a related bid and zero otherwise.

\section{Model}

A logit regression model is used to test hypotheses 1,2,3, and 4. Separate logit regressions were run for each measure of post-abandonment discipline - announced changes in strategy, CEO replacement, significant asset disposals, and external discipline. Further, we include another measure of postabandonment discipline, where a causal link from changes in strategy and/or CEO replacement to significant asset disposals is observed. The dependent variable equals one if a firm experiences post-abandonment disciplinary responses as defined above, and zero if it does not. The model includes control variables for contingent factors in the bidding process which can influence abandonment, size, and profitability. There are a number of factors which can influence the course of a bidding process.

The presence of rival bidders, particularly if they are offering cash, tends to generate abandonment related to the terms of a bid rather than its motives (Kummer \& Steger, 2008). Rival bidders are attracted, either by the target as a "white knight," or because they want the target's assets. Competitive bidding pushes up the price, reducing the opportunity for bidders to derive value from a transaction. A bidder not wishing to overpay may therefore abandon a bid to avoid the winner's curse (Roll, 1986). A dummy variable is used which takes a value of one if there is a rival bidder(s) and zero otherwise.

Target management resistance is another contingent factor influencing abandonment (Branch, Wang, \& Yang, 2008; Muehlfeld et al., 2007). Such resistance is linked to a number of factors, such as the means of payment and the presence of rival bids (Kummer \& Steger, 2008). Bidders looking to maximize returns from a transaction may make an opportunistic bid. Target managers may resist because they think the bid undervalues their company. Such resistance is in their shareholders' interest, as these managers are trying to elicit a higher price, perhaps by initiating an auction process. A dummy variable is used which takes a value of one if there is target management resistance to an initial bid and zero otherwise.

Size is a control variable measured as the natural logarithm of the total assets of the bidding firm at the end of the financial year preceding the bid. Its inclusion is based on the argument that the size of a firm can have a major impact on the response to abandonment, as larger joint stock firms are more likely to suffer problems associated with the separation of ownership and control, but are less likely to be subject to the external discipline of the market for corporate control. A control variable reflecting the profitability of the bidding firm is also included. Poor profitability may worry principals concerned that managers are overstretching themselves with bids, rather than focusing on the internal restructuring necessary to improve profitability. We measure profitability using the average return on capital employed over two full financial years preceding the bid. Table 3 shows the shortened names for the independent variables, their operational definitions, the sources of data and their expected signs.

Based on the model, the probability of a bidding firm experiencing a post-abandonment disciplinary response is:

$$
e_{i}^{\eta} /\left(1+e_{i}^{\eta}\right)
$$

$$
\text { where } \begin{aligned}
\mathrm{e}_{\mathrm{i}}^{\eta}=\beta_{0} & +\beta_{1} \text { PID }+\beta_{2} \text { CAR }+\beta_{3} \text { PEQ } \\
& +\beta_{4} \text { RTGT }+\beta_{5} \text { RIVAL }+\beta_{6} \text { TRES } \\
& +\beta_{7} \text { SIZE }+\beta_{8} \text { PERF }+\varepsilon_{t}
\end{aligned}
$$

Following Aiken and West (1991), we center the independent variables to enable a more meaningful interpretation of the logit regression results. We choose to center the variables on their median values as, with the inclusion of several dummy variables, no firm actually possesses the mean characteristics. As a result, the exponent of the intercept coefficient of the logistic regression of (2) is the predicted odds of post-abandonment discipline for the median firm. Consequently, we can use the "median firm" as a benchmark for the calculation of the marginal impact of the independent variables on the probability of postabandonment discipline (Long, 1997).

We propose that less independent boards use additional information signals from transaction characteristics to exert control, force abandonment and discipline senior managers subsequently. Consequently, changes in the proportion of non-executive directors on the board (PID), holding everything else constant, should change the marginal impact of the independent variables on post-abandonment discipline. To test this, we extend the model to include terms measuring the interaction between board independence and each characteristic anticipated to convey information during the bidding process. This extended model tests hypotheses $2 \mathrm{a}, 3 \mathrm{a}$, and $4 a$, respectively. To denote the interaction terms, I is added to the independent variable names. This extended model is shown in equation (3) below:

$$
\begin{aligned}
e_{i}^{\eta}=\beta_{0} & +\beta_{1} \text { PID }+\beta_{2} \text { CAR }+\beta_{3} \text { PEQ }+\beta_{4} \text { RTGT }+\beta_{5} \text { RIVAL } \\
& +\beta_{6} \text { TRES }+\beta_{7} \text { SIZE }+\beta_{8} \text { PERF }+\beta_{9} \text { ICAR } \\
& +\beta_{10} \text { IPEQ }+\beta_{11} \text { IRTGT }+\varepsilon_{t}
\end{aligned}
$$

We test the interactions as a "chunk," comparing the goodness-of-fit of the model without the interactive terms against the model with the interactive terms (Kleinbaum, 1992). We use Hosmer-Lemeshow (H-L) tests to measure the goodness-of-fit. If the difference in fit is trivial, this suggests that interactions between PID and information revealed during the bidding process are not material to the probability of post-abandonment discipline. In contrast, a significant result suggests that at least one interaction term is important. If this is the case, we use a backward elimination strategy to identify significant interactions. We analyze the significant interactions using procedures described by Jaccard (2001). The results are presented and discussed in the following section. 
TABLE 3

Independent Variable Definitions, Data Sources and Expected Signs

Variable

(Abbreviated name)

PID (Board

independence)

CAR (Share price

reaction to bid)

PEQ (Bid financing)

RTGT (Industrial

relatedness of

bidder and target)

RIVAL (Rival

bidder(s))

TRES (Target

management

resistance)

SIZE

PERF
Expected impact on likelihood of post-abandonment discipline
Dummy variable that takes a value of one if the bidder and target have the same 2-digit SIC and zero otherwise

Dummy variable that takes a value of one if there is a rival bidder(s) and zero otherwise

Dummy variable that takes a value of one if there is target management resistance to an initial bid and zero otherwise

Natural logarithm of the total assets of the bidding firm at the end of the financial year preceding the bid.

Average return on capital employed over two full financial years preceding the bid
Proportion of non-executive directors on the

Cumulative abnormal returns using market model residuals through days -1 to +5 .

Proportion of a bid financed using equity

Bid Documents

News Service

LSE Regulatory

News Service

Press Reports LSE

Regulatory News

Service

Press Reports LSE

Regulatory News

Service

Company Annual

Report

Company Annual

Report

\section{RESULTS}

\section{Descriptive Statistics}

Disciplinary Responses to Abandonment. Table 4 provides descriptive statistics for the disciplinary responses for the sample of 53 failed bidders. The findings indicate that 37.7 percent experienced no disciplinary responses to abandonment. However, a large percentage of the sample announced a change in strategy or CEO replacement - indeed, several firms did both. Where firms announced a change in strategy and/or replaced their CEO, asset disposals were much more likely. There is a significant difference between the incidence of changes in strategy and/or CEO replacement (81.8 percent) in firms experiencing subsequent asset disposals compared to their incidence (43.4 percent) across the whole sample. This suggests that asset divestments are more likely to follow announced changes in strategy, CEO replacement, or both, supporting the concept of a disciplinary sequence triggered by information revealed during the bidding process.

Determinants of Post-Abandonment Responses. Table 5 reports the descriptive statistics for the entire sample of abandoned bidders. The mean sample firm size was $£ 19648.91 \mathrm{~m}$, substantially higher than the median firm size of $£ 140.79 m$,
TABLE 4

Incidence of Post Abandonment Events

\begin{tabular}{lcr}
\hline Disciplinary responses & $\begin{array}{c}\text { Percentage } \\
\text { of firms }\end{array}$ & $\mathrm{n}$ \\
\hline None & 37.7 & 20 \\
Announced changes in strategy & 15.1 & 8 \\
CEO replacement & 37.7 & 20 \\
Significant asset divestments & 20.75 & 11 \\
Subsequent acquisition & 9.4 & 6 \\
Subsequent bankruptcy & 11.3 & 5 \\
Disciplinary process & $81.8^{*}$ & \\
Firms where significant asset sales were & & \\
preceded by announced changes in & & \\
strategy and /or CEO replacement (as a & & \\
percentage of all firms which have & & \\
significant asset sales) & 43.4 \\
Percentage of firms with significant asset & & \\
sales in the whole sample & & \\
\hline
\end{tabular}

*denotes that the difference in percentages is significant at the $5 \%$ level. 
TABLE 5

Descriptive Statistics for the Sample

\begin{tabular}{|c|c|c|}
\hline Variable & $\begin{array}{l}\text { Sample } \\
\text { mean }\end{array}$ & $\begin{array}{l}\text { Sample } \\
\text { median }\end{array}$ \\
\hline Non-executive directors (\%) (PID) & 47.51 & 50.00 \\
\hline $\begin{array}{l}\text { Bid announcement return }(\%) \text {, } \\
(\text { Days }-5,+1)(\text { CAR })\end{array}$ & -1.31 & -1.91 \\
\hline $\begin{array}{l}\text { Proportion of equity financing } \\
\text { (PEQ) }\end{array}$ & 0.68 & 1 \\
\hline $\begin{array}{l}\text { Target with same 2-digit SIC } \\
\text { (RTGT) }\end{array}$ & 0.81 & 1 \\
\hline Bids with rival bidder(s) (RIVAL) & 0.57 & 1 \\
\hline $\begin{array}{l}\text { Target management resistance } \\
\text { (TRES) }\end{array}$ & 0.58 & 1 \\
\hline Total assets (£m) (SIZE) & 19648.91 & 140.79 \\
\hline $\begin{array}{l}\text { Average return on capital (\%) } \\
\text { (PERF) }\end{array}$ & 8.92 & 6.90 \\
\hline
\end{tabular}

For all dummy variables, the reported numbers in the sample mean column indicate the proportion of sample firms that carry a value " 1 " for respective variables.

demonstrating a positive skew for the distribution of this characteristic.

The correlation matrix for the independent variables is shown in Table 6. There are no significant correlations, suggesting that the findings of the models are not affected by potential multicollinearity.

\section{Logistic Regression Results}

The results from implementing variations of the regression model expressed in equation (2) are presented in Tables 7-11. We shall discuss the effect of each independent variable on the probability of experiencing post-abandonment discipline in the context of firms possessing median characteristics (the median firm hereafter).
The results show that the odds of the median firm announcing a change in strategy within two years of abandonment was only 0.063 . The only variable with a significant influence on this disciplinary outcome is the industrial relatedness of the target. The median firm has a related target, but the results indicate that if the bid was for an unrelated target, the odds of announcing a change in strategy subsequently was 22 times greater. This supports hypothesis 4, suggesting a significant relationship between unrelated diversification and postabandonment discipline. This suggests that such bids signal empire-building by managers and/or the diversification of their personal risk. The results support a governance role for the bidding process in abandoning such bids and making strategic changes afterwards. The results do not support any of the remaining hypotheses. Neither board composition (PID) nor bid financing (PEQ) were found to have a significant influence on the probability of changing strategy after abandonment. While, the variable CAR has an odds ratio of 6.548 , in practice, this means that a 1 percent decrease in CAR increases the probability of post-abandonment discipline by only.001.

The results do not support hypotheses 1,2, or 3 regarding CEO replacement as a disciplinary response to abandonment. In contrast, the results suggest that bids for unrelated targets are five times more likely to produce CEO replacement compared with bids for related targets. This supports hypothesis 4 .

The results indicate that the predicted odds of the median firm making significant asset disposals after abandonment is .037. Again, the industrial relatedness of the target has a significant impact on the probability of this aspect of postabandonment discipline. If the value of this variable moves from 1 (related target) to 0 (unrelated target), the predicted odds of post-abandonment discipline rises 10 -fold. This supports hypothesis 4 , suggesting diversifying bids signal excessive diversification by managers. After abandonment, there is a refocusing of activities. The results do not support any of the other hypotheses.

In many cases, a causal link can be drawn between announced changes in strategy and significant asset divestment. Similarly, a causal link can be drawn from CEO replacement to significant asset disposals. Indeed, several firms in the sample replaced their CEO, announced a

TABLE 6

Correlation Matrix $(n=53)$

\begin{tabular}{|c|c|c|c|c|c|c|c|c|}
\hline & PID & CAR & PEQ & RTGT & RIVAL & TRES & SIZE & PERF \\
\hline \multicolumn{9}{|l|}{ PID } \\
\hline CAR & -.103 & & & & & & & \\
\hline PEQ & -.108 & .155 & & & & & & \\
\hline RTGT & .317 & .001 & .006 & & & & & \\
\hline RIVAL & .000 & .095 & .043 & -.022 & & & & \\
\hline TRES & .002 & .165 & -.185 & -.141 & -.120 & & & \\
\hline SIZE & .280 & -.143 & -.150 & .248 & .134 & .1154 & & \\
\hline PERF & .148 & -.180 & .079 & .270 & .245 & -.082 & .170 & \\
\hline
\end{tabular}

** $\mathrm{p}<.05$ 
TABLE 7

Regression Results for Announced Change in Strategy as Post-Abandonment Discipline

(a) Regression results

Coefficient

Variable

Intercept

PID

CAR

PEQ

RTGT

Control variables

RIVAL

TRES

SIZE

PERF (standard error)

$-2.762(1.021)^{* * * *}$

$-.293(3.372)$

$-1.880(3.644)$

$.183(.954)$

$-3.100(1.088)^{* * * *}$

$-1.255(.975)$
$.636(.931)$
$.132(.142)$
$.317(1.551)$

(b) Associated marginal impact of each independent variable

\begin{tabular}{lcc}
\hline & $\begin{array}{c}\text { Predicted odds for } \\
\text { post-abandonment discipline }\end{array}$ & $\begin{array}{c}\text { Odds ratio for variable } \\
\text { vs median values }\end{array}$ \\
Median firm & .063 & \\
PID & .085 & 1.341 \\
CAR & .414 & 6.549 \\
PEQ & .053 & .833 \\
RTGT & 1.402 & 22.198 \\
& & \\
Control variables & & \\
RIVAL & .222 & 3.510 \\
TRES & .033 & .529 \\
SIZE & .0554 & .877 \\
PERF & .046 & .543
\end{tabular}

In panel (a) the standard errors are shown in parentheses. In panel (b) predicted odds for independent variables are calculated for 1 unit changes consistent with expected signs while holding values of other variables at zero.

${ }^{*} \mathrm{p}<.10$

$* * * \mathrm{p}<.05$
$* * * \mathrm{p}<.01$

TABLE 8

Regression Results for CEO Replacement as Post-Abandonment Discipline

(a) Regression results

\begin{tabular}{|c|c|c|c|c|}
\hline Variable & $\begin{array}{c}\text { Coefficient } \\
\text { (standard error) }\end{array}$ & & $\begin{array}{l}\text { Predicted odds for } \\
\text { post-abandonment discipline }\end{array}$ & $\begin{array}{l}\text { Odds ratio for variable } \\
\text { vs median values }\end{array}$ \\
\hline Intercept & $-2.353(1.079)$ & Median firm & .095 & \\
\hline PID & 1.289 (1.954) & PID & .026 & .276 \\
\hline CAR & $5.284(5.108)$ & CAR & .001 & .005 \\
\hline PEQ & $-.786(.807)$ & PEQ & .209 & 2.196 \\
\hline RTGT & $-1.653(1.524)$ & RTGT & .497 & 5.224 \\
\hline Control variables & & Control variables & & \\
\hline RIVAL & $-1.529(.718)$ & RIVAL & .437 & 4.614 \\
\hline TRES & $-1.308(.849)$ & TRES & .352 & 3.699 \\
\hline SIZE & $.123(.117)$ & SIZE & .084 & .885 \\
\hline PERF & $2.732(2.484)$ & PERF & .006 & .065 \\
\hline
\end{tabular}

In panel (a) the standard errors are shown in parentheses. In panel (b) predicted odds for independent variables are calculated for 1 unit changes consistent with expected signs while holding values of other variables at zero.

${ }^{*} \mathrm{p}<.10$

$* * \mathrm{p}<.05$

${ }_{* * * *} \mathrm{p}<.01$

retrenchment strategy, and made significant asset disposals. We include a measure of post-abandonment discipline that distinguishes cases where this disciplinary sequence is established. The results echo those for the regressions with announced changes in strategy and significant asset divestments as the dependent variable. This clearly indicates that the industrial relatedness of a target has a significant impact on the likelihood of this disciplinary sequence. A bid for an unrelated target raises the predicted odds of such disciplinary sequences 18.07 times. Again, this result 
TABLE 9

Regression Results for Significant Divestments as Post-Abandonment Discipline

(a) Regression results

Coefficient

Variable

Intercept

PID

CAR

PEQ

RTGT

Control variables

RIVAL

TRES

SIZE

PERF (standard error)

(b) Associated marginal impact of each independent variable

\begin{tabular}{lcc}
\hline & $\begin{array}{c}\text { Predicted odds for } \\
\text { post-abandonment discipline }\end{array}$ & $\begin{array}{c}\text { Odds ratio for variable } \\
\text { vs median values }\end{array}$ \\
Median firm & .037 & \\
PID & .117 & 3.207 \\
CAR & .032 & .874 \\
PEQ & .019 & .509 \\
RTGT & .392 & 10.722 \\
& & \\
Control variables & & \\
RIVAL & .370 & 10.115 \\
TRES & .062 & 1.707 \\
SIZE & .045 & 1.241 \\
PERF & .331 & 9.068
\end{tabular}

In panel (a) the standard errors are shown in parentheses. In panel (b) predicted odds for independent variables are calculated for 1 unit changes consistent with expected signs while holding values of other variables at zero.

${ }^{*} \mathrm{p}<.10$

$* * \mathrm{p}<.05$

TABLE 10

Regression Results for Sequential Process of Post-Abandonment Discipline

(a) Regression results

Coefficient

Variable

(standard error) (b) Associated marginal impact of each independent variable

\begin{tabular}{lcc}
\hline & $\begin{array}{c}\text { Predicted odds for } \\
\text { post-abandonment discipline }\end{array}$ & $\begin{array}{c}\text { Odds ratio for variable } \\
\text { vs median values }\end{array}$ \\
Median firm & .015 & \\
PID & .072 & 4.767 \\
CAR & .001 & .037 \\
PEQ & .015 & 1.005 \\
RTGT & .273 & 18.067 \\
Control variables & & \\
RIVAL & .154 & \\
TRES & .038 & 2.146 \\
SIZE & .0267 & 2.509 \\
PERF & .069 & 1.771 \\
& & 4.552
\end{tabular}

Intercept

PID

CAR

PEQ

RTGT

Control variables

RIVAL

TRES

SIZE

PERF

$$
\begin{aligned}
& -4.194(2.038)^{* *} \\
& -1.562(3.245) \\
& 3.310(4.621) \\
& -.005(1.246) \\
& -2.894(1.654)^{*}
\end{aligned}
$$

$-2.325(1.711)$

$-.920(1.410)$

$.571(.182)^{* *}$

$-1.516(4.776)$

Notes: In panel (a) the standard errors are shown in parentheses. In panel (b) predicted odds for independent variables are calculated for 1 unit changes consistent with expected signs while holding values of other variables at zero.

${ }^{*} \mathrm{p}<.10$

${ }_{* * * *}^{*}<.05$

$* * * \mathrm{p}<.01$

is consistent with hypothesis 4 . In such cases abandonment seems to be driven by information revealed that bids are driven by managerial empire-building or diversification of their personal risk, producing discipline through CEO replacement, and strategic changes involving retrenchment and the refocusing of activities.

Interestingly, the median firm has predicted odds of .410 for experiencing external changes through corporate and 
TABLE 11

Regression Results for External Control Events as Post-Abandonment Discipline

(a) Regression results

Coefficient

Variable (standard error) (b) Associated marginal impact of each independent variable

\begin{tabular}{lcllr} 
Variable & $\begin{array}{c}\text { Coefficient } \\
\text { (standard error) }\end{array}$ & & $\begin{array}{c}\text { Predicted odds for } \\
\text { post-abandonment discipline }\end{array}$ & $\begin{array}{c}\text { Odds ratio for variable } \\
\text { vs median values }\end{array}$ \\
\hline Intercept & $-.893(.434)$ & Median firm & .410 & .635 \\
PID & $.454(1.277)$ & PID & .260 & 1.026 \\
CAR & $-2.552(2.767)$ & CAR & .420 & .502 \\
PEQ & $.689(.451)$ & PEQ & .206 & .936 \\
RTGT & $.066(.724)$ & RTGT & .383 & 1.123 \\
Control variables & & Control variables & .460 & .484 \\
RIVAL & $-.116(.389)$ & RIVAL & .198 & 1.156 \\
TRES & $.727(.446)$ & TRES & .473 & .151 \\
SIZE & $-.145(.089)$ & SIZE & .062 & \\
PERF & $1.888(.893)$ & PERF &
\end{tabular}

In panel (a) the standard errors are shown in parentheses. In panel (b) predicted odds for independent variables are calculated for 1 unit changes consistent with expected signs while holding values of other variables at zero.

${ }^{*} \mathrm{p}<.10$

$* * \mathrm{p}<.05$

$* * * \mathrm{p}<.01$

financial restructuring in bankruptcy, or through the market for corporate control. However, the results do not support hypotheses 1, 2,3, and 4. Changes in the independent variables do not have a significant impact on the predicted odds of experiencing this aspect of post-abandonment discipline.

In the regressions with asset divestments and disciplinary sequences as measures of post-abandonment discipline, the coefficients on the control variable for SIZE are significant and positive. This suggests that the larger a firm, the higher the likelihood it will experience disciplinary responses culminating in asset disposals. This is consistent with the argument that large firms are more likely to be excessively diversified, requiring retrenchment and a refocusing of its activities.

In addition, the coefficient on the control variable, RI$\mathrm{VAL}$, in the regression for asset divestment is significant and negative. With a rival bidder present, abandonment is likely to be driven by price and not information revelation related to motives. This is supported by the low predicted odds for these disciplinary responses for the median firm. However, if the value for this variable changes, from 1 (rival bidder) to 0 (no rival bidder), the predicted odds of postabandonment asset divestments increases by a factor of 10. This evidence is consistent with the hypothesis that, without a rival bidder, abandonment is more likely to be driven by information revelation that a bid is driven by managerial empire-building or diversification of personal risk. Cumulatively, a firm at the third quartile of corporate size, making a bid for an unrelated target with no rival bidder, is approximately 32 times more likely to conduct significant asset divestments compared to the median firm.

\section{Interactive Terms}

In our framework, we propose that less independent boards will use the additional information signal provided by bid characteristics to exert control over senior managers to force abandonment. Consequently, lower board independence should amplify the impact of bid characteristics on the likelihood of post-abandonment discipline. This is characterized in hypotheses $2 \mathrm{a}, 3 \mathrm{a}$, and $4 \mathrm{a}$. To test these hypotheses, we include interaction terms between PID and CAR, PEQ, and RTGT, respectively.

Table 12 shows the results of the H-L tests conducted, comparing the goodness-of-fit for the model without, compared to the model with, interactive terms. The results show that the addition of interactive terms does not improve the fit of the regression model explaining post-abandonment disciplinary responses. This does not support the view that reduced board independence intensifies the impact of bid characteristics on the likelihood of post-abandonment disciplinary responses.

\section{Implications of the Results}

The results provide support for the proposition that, in certain circumstances, the process of abandonment does play a governance role in bidding firms, mitigating principal-agent conflicts. Hypotheses 1, 2, and 3 are not supported by the results. This suggests that firms' board composition, bid financing, and the share price reaction to bids, are not significant sources of information regarding agency conflicts in this context. In contrast, our findings reveal that the key characteristic driving changes in strategy and significant asset sales is the industrial relatedness of the bidder and target. This supports hypothesis 4 . The results 
TABLE 12

Test Statistics for Model With and Without Interactive Terms

\begin{tabular}{lccccc}
\hline & \multicolumn{5}{c}{ Post-abandonment disciplinary events } \\
\cline { 2 - 6 } & $\begin{array}{c}\text { Announced changes } \\
\text { in strategy }\end{array}$ & $\begin{array}{c}\text { CEO } \\
\text { replacement }\end{array}$ & $\begin{array}{c}\text { Significant assets } \\
\text { divestments }\end{array}$ & $\begin{array}{c}\text { Disciplinary } \\
\text { process }\end{array}$ & $\begin{array}{c}\text { External } \\
\text { discipline }\end{array}$ \\
\hline $\begin{array}{l}\text { H-L test statistic without } \\
\text { interactive terms }\end{array}$ & $10.765(.215)$ & $16.374(.037)^{* *}$ & $5.262(.729)$ & $2.499(.962)$ & $7.523(.481)$ \\
$\begin{array}{l}\text { H-L test statistic with all } \\
\text { interactive terms }\end{array}$ & $3.932(.863)$ & $9.137(.331)$ & $2.912(.940)$ & $2.634(.955)$ & $7.166(.519)$ \\
\hline
\end{tabular}

Associated probabilities are shown in parentheses.

${ }^{*} \mathrm{p}<.10$

$* * \mathrm{p}<.05$

$* * * \mathrm{p}<.01$

imply that firms that abandon bids for unrelated targets are more likely to announce changes in strategy afterwards, involving significant net asset sales. Unrelated bids may be interpreted as a sign of either excessive diversification by bidding managers' empire-building (Jensen, 1986) or managers' diversifying their own firm-specific risk (Amihud \& Lev, 1981). The disciplinary response is consistent with this view: a retrenchment of activities after abandonment, removing non-core, "value-destroying" elements of the company.

There is no evidence of any interaction between the extent of board independence and information revealed by bid characteristics influencing the extent of post-abandonment discipline. This does not provide support for the proposed process whereby less independent boards can use bid characteristics to overcome information asymmetries they face. Indeed, board independence does not have a significant impact on the likelihood of post-abandonment discipline. This supports the view of an ambiguous role for board composition (Kumar \& Sivaramakrishnan, 2008).

\section{CONCLUSION}

\section{Summary}

This research has contributed to the literature by (i) extending the analysis of the governance role of abandoned acquisitions to the post-abandonment phase, tracing the extent of disciplinary responses in bidding firms after abandonment and (ii) examining the relationship between characteristics which indicate agency problems and the degree of post-abandonment discipline in a UK corporate environment. Seven hypotheses were developed to test which, if any, agency characteristics reveal information about bids driven by managerial self-interest and produce post-abandonment discipline. The hypotheses were tested using data from a sample of 53 abandoned acquisitions involving UK publicly listed corporations as bidders.

In certain circumstances, a governance role for the bidding process surrounding abandoned acquisitions is supported by the evidence. Corporate governance mechanisms culminating in internal discipline surrounding asset divestments and down-sizing seem to be triggered by bids for unrelated targets. This suggests that principal-agent problems in these firms produced excessive diversification by executives' empire-building or diversification of personal risk. There is no evidence that more severe external discipline involving changes in control (subsequent acquisition or bankruptcy) is related to board composition or transaction characteristics.

\section{Limitations and Further Research}

The results are subject to limitations inherent in the research design in several areas. Despite our sample of bidders in abandoned takeovers representing a significant share of all such firms over the sample period, work utilizing a larger number of bidding firms could produce additional robustness to the analysis of the distinctive characteristics of discipline involving abandoned acquisitions. This is particularly the case when analyzing the interactions between board independence and transaction characteristics. Consequently, further research could re-examine the hypotheses of this study using a larger sample of bidding firms. In addition, while we conceptualize a reasoned elucidation of post-abandonment disciplinary sequences, this could benefit from additional research. In particular, future research could develop different propositions regarding post-abandonment discipline and, by comparing against our results, further enhance our understanding of the governance mechanisms involving abandoned acquisitions. Furthermore, such work could also be conducted using abandoned acquisitions in other jurisdictions where the market for corporate control is anticipated to be an important corporate governance mechanism such as the US, Canada, and Australia.

\section{Implications of the Study}

Divergent shareholders and managers' interests remain an important issue for corporate governance in Anglo-American corporate environments. Our results indicate that the bidding process of abandoned acquisitions can, in certain circumstances, play a governance role addressing problems arising from agency conflicts in firms. The findings imply that the 
market for corporate control can distinguish between abandoned bidders which require discipline from those that do not. This implies that significant corporate control events, such as acquisitions, are important mechanisms through which information about managerial motivations are revealed. However, the proposed mechanism by which boards of different composition interpret bid characteristics is not supported by the results. There is no evidence that weaker boards respond to bid characteristics differently, producing a difference in the likelihood of post-abandonment discipline. This is important given the emphasis on board independence in regulatory reform surrounding corporate governance. It suggests that the information is used by boards to decide whether a bid is worthwhile, not just in isolation, but in the context of other information. It may well be that board interactions, and their response to the signals of shareholders are more subtle and complex, governed by a range of factors, rather than just the independence of directors.

Our results suggest that discipline depends on the nature of problems arising from the manager-shareholder relationship identified. Consequently, larger, excessively diversified firms do not tend to suffer substantial control changes as a result of bid abandonment. Instead, they remain independent, focusing instead on altering strategy; from expansion to retrenchment. So long as boards/agents respond appropriately, principals are happy to leave them in place. External discipline through the market for corporate control is not necessary. This appears to be a manifestation of increased "shareholder activism" in corporate control. Indeed, the promotion by UK regulators of more regular meetings between companies' boards of directors and their major shareholders will improve signals to managers. This should produce more value-enhancing acquisition decisions.

\section{ACKNOWLEDGEMENTS}

The authors would like to thank the referees and associate editor for their helpful comments on earlier drafts of the paper.

\section{REFERENCES}

Adams, R. \& Ferrera, D. 2007. A theory of friendly boards. Journal of Finance, 62: 217-250.

Adams, R., Hermalin, B., \& Weisbach, M. 2010. The role of boards of directors in corporate governance: A conceptual framework and survey. Journal of Economic Literature, 48: 58-107.

Ahn, S. \& Walker, M. 2007. Corporate governance and the spin-off decision. Journal of Corporate Finance, 13: 76-93.

Aiken, L. \& West, S. 1991. Multiple regression: Testing and interpreting interactions. London: Sage Publications.

Amihud, Y. \& Lev, B. 1981. Risk reduction as managerial motive for conglomerate mergers. Bell Journal of Economics, 12: 605-617.

Barclay, M. \& Smith, Jr., C. 1995. The maturity structure of corporate debt. The Journal of Finance, 50: 609-631.

Berle, A. A. \& Means, G. C. 1932. The modern corporation and property. New York: Harcourt, Brace and World.

Bhagat, S. \& Black, B. 2002. The non-correlation between board independence and long-term firm performance. Journal of Corporation Law, 27: 231-274.

Branch, B., Wang, J., \& Yang, T. 2008. A note on takeover success prediction. International Review of Financial Analysis, 17: 1186-1193.
Chang, S. \& Suk, D. Y. 1998. Failed takeovers, method of payment and bidder returns. The Financial Review, 33: 77-84.

Chen, X., Harford, J., \& Li, K. 2007. Monitoring: Which institutions matter? Journal of Financial Economics, 86: 279-305.

Cornett, M. M., Hovekimian, G., Paulia, D., \& Tehranian, H. 2003. The impact of merger-shareholder conflict on acquiring bank returns. Journal of Banking and Finance, 27: 103-131.

Dalton, D. R., Daily, C. M., Ellstrand, A. E., \& Johnson, J. L. 1998. Metaanalytic reviews of board composition, leadership structure, and financial performance. Strategic Management Journal, 19: 269-290.

Demb, A. \& Neubauer, F. 1992. The corporate board: Confronting the paradoxes. Oxford: Oxford University Press.

Denis, D. J. \& Serrano, J. M. 1996. Active investors and management turnover following unsuccessful control contests. Journal of Financial Economics, 40: 239-266.

Dominguez-Martinez, S., Swank, O. H., \& Visser, B. 2008. In defense of boards. Journal of Economics and Management Strategy, 17: 667-682.

Financial Reporting Council. 2012. UK Corporate Governance Code. Gaspar, J., Massa, M., \& Matos, P. 2005. Shareholder investment horizons and the market for corporate control. Journal of Financial Economics, 76: 145-165.

Gillette, A. B., Noe, T. H., \& Starks, L. T. 2008. Corporate board composition, protocols and voting behaviour: Experimental evidence. The Journal of Finance, 58: 1997-2031

Goranova, M., Alessandri T., Brandes, P., \& Dharwadkar, P. 2007. Managerial ownership and corporate diversification: A longitudinal view. Strategic Management Journal, 28: 211-225.

Gregory, A. 2005. The long-run abnormal performance of UK acquirers and the free cash flow hypothesis. Journal of Business, Finance $\mathcal{E}$ Accounting, 32: 777-813.

Haynes, M., Thompson, S., \& Wright, M. 2000. The determinants of corporate divestment in the UK. International Journal of Industrial Organisation, 18: 1201-1222.

Hermalin, B. \& Weisbach, M. 1998. The determinants of board composition. RAND Journal of Economics, 19: 589-606.

Hirshleifer, D. \& Thakor, A. 1994. Managerial performance, board of directors and takeover bidding. Journal of Corporate Finance, 1: 295-325.

Holl, P. \& Pickering, J. 1988. The determinants and effects of actual abandoned and contested mergers. Managerial and Decision Economics, 9: 1-19.

Holmstrom, B. 2005. Pay without performance and the managerial power hypothesis: A comment. Journal of Corporation Law, 30: 703-713.

Hotchkiss, E., Qian, J., \& Song, W. 2005. Holdups, renegotiation, and deal protection in mergers. Working Paper. Available at: http:/ / ssrn.com/abstract $=705365$

Huson, M. R., Parrino, R., \& Starks, L. T. 2001. Internal monitoring mechanisms and $\mathrm{CEO}$ turnover: A long-term perspective. The Journal of Finance, 56: 2265-2297.

Jaccard, J. 2001. Interaction effects in logistic regressions. Sage University papers in Quantitative Applications in the Social Sciences, No. 135, Thousand Oaks, Sage.

Jensen, M. 1986. Agency costs of free-cash flow, corporate finance, and takeovers. American Economic Review, 76: 323-329.

Jensen, M. \& Meckling, W. H. 1976. Theory of the firm: Managerial behaviour, agency costs and ownership structure. Journal of Financial Economics, 3: 305-360.

Kennedy, V. \& Limmack, R. 1996. Takeover activity, CEO turnover and the market for corporate control. Journal of Business, Finance $\mathcal{E}$ Accounting, 23: 267-285.

Kleinbaum, D. G. 1992. Logistic regression: A self-learning text. New York: Springer.

Kumar, P. \& Sivaramakrishnan, K. 2008. Who monitors the monitor? The effect of board independence on executive compensation and firm value. Review of Financial Studies, 21: 1371-1401. 
Kummer, C. \& Steger, U. 2008. Why mergers and acquisitions waves reoccur: The vicious circle from pressure to failure. Strategic Management Review, 2: 44-63.

Lane, P., Cannella, A., \& Lubatkin, M. 1998. Agency problems as antecedents to unrelated mergers and diversification: Amihud and Lev reconsidered. Strategic Management Journal, 19: 555-578.

Lehn, K. \& Zhao, M. 2006. CEO turnover after acquisitions: Are bad bidders acquired? The Journal of Finance, 61: 1759-1811.

Limmack, R. 1994. Synergy or new information as a source of wealth change in acquisitions: The case of abandoned bids. Accounting and Business Research, 24: 255-265.

Long, J. S. 1997. Regression models for categorical and limited dependent variables. Thousand Oaks, CA: Sage.

Luo, Y. 2005. Do insiders learn from outsiders? Evidence from mergers and acquisitions. The Journal of Finance, 60: 1951-1982

Manne, H. G. 1965. Mergers and the market for corporate control. Journal of Political Economy, 73: 110-120.

Masulis, R. W., Cong, W., \& Xie, F. 2009. Agency problems at dualclass companies. The Journal of Finance, 64: 1697-1727.

Mitchell, M. L. \& Lehn, K. 1990. Do bad bidders become good targets? Journal of Political Economy, 98: 372-398.

Muehlfeld, K., Sahib, P., \& Van Witteloostuijn, A. 2007. Completion or abandonment of mergers and acquisitions: Evidence from the newspaper industry, 1981-2000. Journal of Media Economics, 20: 107-137.

Muth, M. M. \& Donaldson, L. 1998. Stewardship theory and board structure: Contingency approach. Corporate Governance: An International Review, 6: 5-28.

Myers, S. C. \& Majluf, N. S. 1984. Corporate financing and investment decisions when firms have information that investors do not have. Journal of Financial Economics, 13: 187-221.

O'Sullivan, N. \& Wong, P. 2005. The governance role of takeovers. In K. Keasey, S. Thompson, and M. Wright (Eds.), Corporate governance: Accountability, enterprise and international comparisons, 155-176. Chichester: John Wiley \& Sons.

Paul, D. L. 2007. Board composition and corrective action: Evidence from corporate responses to bad acquisition bids. Journal of Financial and Quantitative Analysis, 42: 759-784.

Peltier, S. 2004. Mergers and acquisitions in the media industries: Were failures really unforeseeable? Journal of Media Economics, 17: 261-278.

Perry, T. \& Shivdasani, A. 2005 Do boards affect performance? Evidence from corporate restructuring. Journal of Business, 78: 1403-1431.
Pickering, J. F. 1983. The causes and consequences of abandoned mergers. Journal of Industrial Economics, 31: 267-281.

Powell, R. \& Stark, A. W. 2005. Does operating performance increase post-takeover for UK takeovers? A comparison of performance measures and benchmarks. Journal of Corporate Finance, 24: 1009-1030.

Ravina, E. \& Sapienza, P. 2010. What do independent directors know? Evidence from their trading. Review of Financial Studies, 23: 963-1003.

Roll, R. 1986. The hubris hypothesis of corporate control. Journal of Business, 59: 197-216.

Ross, S. A. 1973. The economic theory of agency: The principal's problem. American Economic Revieww, 63: 134-139.

Shleifer, A. \& Vishny, R. M. 2003. Stock market driven acquisitions. Journal of Financial Economics, 70: 295-311.

Taffler, R. \& Holl, P. 1991. Abandoned mergers and the market for corporate control. Managerial and Decision Economics, 12: 271-280.

Tian, G. Y. \& Twite, G. 2011. Corporate governance, external market discipline and firm productivity. Journal of Corporate Finance, 17: 403-417.

Wong, P. \& O'Sullivan, N. 2001. The determinants and consequences of abandoned takeovers. Journal of Economic Surveys, 15: 145-186.

Michael McCann is a principal lecturer in Economics at Nottingham Business School, at Nottingham Trent University, where he has worked since 2003. His research primarily concerns corporate governance, acquisitions, and strategic decision making. The particular focus is the role of the market for corporate control in corporate governance. He utilizes both quantitative and qualitative research methods to analyze various aspects of the acquisition process and its aftermath.

Robert Ackrill is Professor of European Economics and Policy at Nottingham Business School, Nottingham Trent University, where he has worked since 2000. His research interests cover a wide range of empirical economic and policy issues and he utilizes diverse analytical tools from across economics and policy science. He has published widely on the dynamics and drivers of EU policies, trade policies, sustainability, and renewable energy. Recent work includes analysis of corporate governance questions, especially regarding variations in implementation across EU countries. 